\title{
GRAMMATICALIZATION IN BOPP
}

\author{
GRAMATICALIZACIÓN EN BOPP
}

\author{
Christian Lehmann \\ University of Erfurt \\ christian.lehmann@uni-erfurt.de \\ ORCID: 0000-0002-9713-9206
}

DOI: $10.1387 /$ veleia.16825

\begin{abstract}
In many diachronic analyses, Franz Bopp underpinned what became known as agglutination theory. In this, he took up earlier and contemporary thinking about linguistic evolution and contributed to the development of modern grammaticalization theory.

Keywords: Franz Bopp, grammaticalization, agglutination theory, language evolution.

Resumen: En muchos análisis diacrónicos, Franz Bopp apuntaló lo que llegó a conocerse como teoría de la aglutinación. En ella, recogió la opinión anterior y la contemporánea sobre evolución lingüística y contribuyó al desarrollo de la moderna teoría de la gramaticalización.

Palabras clave: Franz Bopp, gramaticalización, teoría de la aglutinación, evolución lingüística.
\end{abstract}

Recibido: $14-10-2015$

Informado: 10-3-2016

Definitivo: 25-5-2016

\section{INTRODUCTION}

The aim of the present contribution is to extract, from the work published by Franz Bopp, his contribution to research on grammaticalization. We will briefly sketch the relevant situation in linguistic research when Bopp began publishing, adduce some quotations from his work in order to illustrate his approach, try to generalize from them and throw a brief glance at the impact this work made on more recent linguistics.

The title of this contribution may lead to erroneous expectations. Bopp's work antedates by a century modern linguistic work on grammaticalization. The term was unknown to him. However, the idea of grammaticalization is present in his work, as well as in the work of some of his contemporaries, as will be shown in section $3^{1}$.

\section{The SITUATION OF DiACHRONIC LINGUISTICS}

In setting the stage for the kind of linguistics done by Bopp, the following conditions must be recalled: Franz Bopp embarked on systematic linguistic studies from 1809 on. At that time, ro-

1 I am grateful to two anonymous reviewers for several useful hints. 
manticism fostered curiosity about the origin of language and culture and humanism propagated education based on the standards and the texts of classical antiquity. The prevalent approach in the humanities was the historical approach. However, although comparative linguistic work had been done on several languages (s. Bernabé 1983), available grammars of Indo-European languages were essentially normative grammars. Descriptive linguistics was not established, a large number of grammars of exotic languages discovered in the colonies notwithstanding. Consequently, most of the variation existing in every language escaped researchers of the time. Moreover, the fervent interest in the reconstruction of origins could not be based on historical grammars, which were practically unavailable. One of the very first was Jacob Grimm's Deutsche Grammatik, which started getting published in 1819 and whose second, much more influential edition of 1822 was reviewed by Bopp in 1827 . The only contemporary work of relevance for linguistic theory was done by Wilhelm von Humboldt; but little of it was yet available at that time ${ }^{2}$. The big successes of the natural sciences, thus, of empirical scientific work, of positivism and evolution theory were yet to come. However, the first scientific discoveries and their presentation in the form of "laws" had already started making their impression on the public, so any academic discipline wanting to get a foot in the university system was well advised to follow that model.

Although syntax had existed at least since Apollonios Dyskolos ( $2^{\text {nd }}$ cent. AD), it remained a stepchild in linguistic work until, roughly, the rise of the Neogrammarians and then, after a period of dormancy, again with the rise of generative grammar. This means that there was little syntax in linguistics at Bopp's time. One of the first to vigorously oppose this limitation of grammatical analysis was Wilhelm von Humboldt (1836, 418f):

"Gerade das Höchste und Feinste läßt sich an jenen getrennten Elementen nicht erkennen und kann nur ... in der verbundenen Rede wahrgenommen oder geahndet werden. Nur sie muß man sich überhaupt in allen Untersuchungen, welche in die lebendige Wesenheit der Sprache eindringen sollen, immer als das Wahre und Erste denken. Das Zerschlagen in Wörter und Regeln ist nur ein totes Machwerk wissenschaftlicher Zergliederung"”.

Thus, when Bopp embarked on his enterprise, linguistic analysis was mostly confined to phonological and morphological analysis.

There was no linguistics of the spoken variety of a language. One quite superficial reason for this state of affairs was, of course, the lack of technical equipment to conduct such research on an empirical basis. However, even if this had been available, one may doubt that linguists at Bopp's time would have used it. Of course, the languages of the colonies had been taken notice of both in the form of missionary grammars and in the form of a couple of collections of comparative samples. However, linguistics had been so firmly grounded in a 2000-year old philological and logical tradition that hardly anybody in Europe came up with the idea of a scientific investigation of a spoken language. Linguistics was much less an empirical science than today. Because of its strong bond with philology, the object of study were written texts. It took researchers some time to clarify

2 Since both were members of the Royal Academy of Berlin, Bopp was familiar with Humboldt 1822, while Humboldt 1827 was less accessible.

3 "It is precisely the highest and finest which is not recognizable in those separated elements and can only $\ldots$ be perceived or guessed in connected speech. It is principally only this latter which must be regarded as the true and first thing in all investigations which are meant to penetrate into the living essence of language. The breaking up into words and rules is only a dead botch of scientific dissection". 
the difference between letters and sounds. In 1833, Bopp still speaks of letters, even of a "tönender Buchstabe" (sounding letter, p. 97), instead of sounds. At that time, the conception of phonological change did not differ much from its conception in antiquity, where phonological processes were substitutions of letters.

Turning closer to the subject of the present chapter, the approach to linguistic change at Bopp's time was different from today's. Starting with Bopp, linguists have wanted to find out about general laws of historical change of languages. We consider diachronic laws both as scientifically interesting in their own right, since they make us understand how language works, and as a methodological presupposition for any historical-comparative work which aims at establishing language families and proto-languages. However, as already indicated, historical grammars were all but inexistent at Bopp's time. Consequently, the comparative linguist had to do the historical groundwork for himself and the comparison at the same time. General principles of linguistic change were not available, but were beginning to emerge from such work.

As is well known, the contrast between synchronic and diachronic linguistics was first formulated, even though without these terms, in Gabelentz 1891, 61, to be taken up and established in structural linguistics in Saussure 1916. The contrast was essentially unthinkable at Bopp's time. Even much later, Hermann Paul $(1880,20)$ wrote his famous verdict that there is no scientific study of language but its historical study. In structural linguistics, both the synchronic and the diachronic study of language involve an abstraction from historically observable variation, its systematization and its reduction to general principles. General diachronic linguistics in this sense figured on the Neogrammarians' program, and they did contribute much to it, but were not actually able to establish it on a solid methodological basis, since they essentially confined their object area to one language family. General diachronic linguistics involves typological comparison. This kind of work had started with Schlegel 1808 and was taken a step further by Humboldt, especially in his major work of 1836. As is well known, Bopp did try to apply his approach outside the Indo-European family. However, lacking the methodological foundation just mentioned, he could not succeed.

\section{Grammaticalization up to Bopp}

The histories of the concept and of the term 'grammaticalization' differ a lot. The word Grammatikalisierung or any of its cognates are not found in Bopp's work. The term was coined by Antoine Meillet in his article of 1912 and has since gotten established in linguistics, with some morphological variation. The concept of grammaticalization, in modern understanding (s. Narrog \& Heine [eds.] 2011 for a contemporary survey), comprises a certain kind of — synchronic or diachronic - grammatical variation by which a linguistic sign (of any complexity) becomes more grammatical. Becoming more grammatical means losing in autonomy with respect to use by speakers. With respect to the language system, becoming more grammatical means getting increasingly subjected to the rules of grammar of a particular language. This brings with it reduction in semantic and phonological complexity, in syntagmatic variability and in morphological status. Needless to say, the modern explication of the concept is not to be found in early linguistic work. Nevertheless, the idea that in linguistic change, signs lose their autonomy, becoming parts of host signs and getting reduced in their phonological form, dates back at least to work by Etienne Bonnot de Condillac. In his Essai sur l'origine des connoissances humaines (1746), vol. 2, p. 125f, he sketches a theory of the origin of grammar as follows: Men first put, in discourse, words representing the verb, time, mode, person and number of agent, in this order. 
"Les sons qui rendoient la signification du verbe déterminée, lui étant toujours ajoutés, ne firent bientôt avec lui qu'un seul mot, qui se terminoit différemment selon ses différentes acceptions. Alors le verbe fut regardé comme un nom, qui, quoiqu'indéfini dans son origine, étoit, par la variation de ses temps $\&$ de ses modes, devenu propre à exprimer d'une manière déterminée l'état d'action \& de passion de chaque chose. C'est de la sorte que les hommes parvinrent insensiblement à imaginer les conjugaisons ${ }^{4 \prime}$.

This one source of grammaticalization theory may suffice here. It is particularly important in the present context as we may assume that Bopp's teachers in Paris, Antoine-Léonard de Chézy and Silvestre de Sacy, were familiar with such ideas and passed them on. Another author preceding Bopp and entertaining ideas of grammaticalization was John Horne Tooke. Among Bopp's contemporaries, August Wilhelm Schlegel and Wilhelm von Humboldt must be singled out. They formed their variants of grammaticalization theory simultaneously and in contact with Bopp and published them in Schlegel 1818 and Humboldt 18225, thus, after Bopp's Conjugationssystem, but before his Vergleichende Grammatik. Bopp was familiar with their work. Here is the key passage from Schlegel 1818, 28:

“C'est une invention en quelque façon négative, que celle qui a produit les grammaires analytiques, et la méthode uniformément suivie à cet égard peut se réduire à un seul principe. On dépouille certains mots de leur énergie significative, on ne leur laisse qu'une valeur nominale, pour leur donner un cours plus général et les faire entrer dans la partie élémentaire de la langue. Ces mots deviennent une espèce de papier-monnaie destiné à faciliter la circulation ${ }^{6 "}$.

In the sequel, Schlegel applies this conception chiefly - though not exclusively- to the renewal of Latin morphological categories in the Romance languages.

\section{Bopp's agGLUtination THEORY}

Bopp makes a distinction between the original state of affairs in Indo-European grammar, which is represented in Sanskrit, and the changed situation displayed by all of the other Indo-European languages. Most of the processes of grammaticalization which he diagnoses therefore involve a Sanskrit form as the source and a form of another Indo-European language as the product of the process. The "simple language organism" of Sanskrit is gradually destroyed and replaced by "mechanical compositions, from which, when their elements were no longer recognized, an appearance of a new organism evolved" (Bopp 1816, 11). However, he partly frees himself from the

4 "Given that the sounds which made the meaning of the verb determined [that is, the words coming after the verb] were always added to it, they soon started to form one word with it, which ended differently according to its various senses. So the verb was regarded as a noun which, although indefinite in its origin, had become apt to express, by the variation of its tenses and moods, the state of action and passion of everything in a determined way. In this way, man arrived imperceptibly at inventing conjugation".
5 Relevant excerpts are quoted in Lehmann 2015, ch. I.

6 The invention which produced analytic grammars is somehow a negative one, and the method uniformly applied in this respect may be reduced to a single principle. One strips certain words of their meaningful energy, leaving them only a nominal $[\sim$ structural $]$ value, in order to grant them a more general circulation and to introduce them into the elementary part of language. These words become a sort of paper money, meant to facilitate circulation. 
unconditional veneration as "original" of anything found in Sanskrit by also applying the same analysis to certain inflectional categories of this language which strike him as analyzable. Thus, some inflected forms of Sanskrit are coded by "modifications of the root", but others by "melting the verbum abstractum [s. below] with the stem syllable [i.e. the root] into one word" $(1816,8)$. The younger Indo-European languages take this technique up and apply it in the renewal of original inflection categories. The basic observation on which this analysis proceeds is the following (1816, 95f):

"Neue Worte können in abgeleiteten Sprachen entstehen durch neue Zusammensetzungen von bedeutenden Sylben, nach dem /96/ Prinzip der Ursprache, und es entstehen neue grammatische Formen, wenn die Nebenbestimmungen der Bedeutung, die in der Ursprache durch Umbiegung der Stammsilbe selbst ausgedrückt wurden, an einem angehängten Worte angezeigt werden, dessen Bestandtheile, wenn die Verbindung nicht mehr erkannt wird, für Endbiegungen der Stammsylbe angesehen werden. - Ein Beyspiel, wo im Lateinischen im praes. ein verbum abstract. mit einer attributiven Wurzel verbunden wird, haben wir an possum - pot-sum ${ }^{7 ”}$.

As is clear from this passage and the subsequent text, Bopp does not consider the possibility that new grammatical categories might evolve by this type of grammatical change. Instead, he limits himself to the renewal of what A. W. Schlegel called synthetic morphology by analytic morphology, which latter, however, emerges as renewed synthetic morphology in the ancient Indo-European languages.

Bopp invokes this kind of analysis for several grammatical categories, but above all for verbal desinences. In 1816, 9, he considers essentially two variants of the agglutination process: the welding of the verb root with a following auxiliary and the formation of tempora derivativa (roughly, secondary tenses) on the basis of participles. The former process is already illustrated in the above quotation: Lat. possum 'I can' derives from *pot(is) sum 'I am able'. According to Bopp, there is only one genuine verb, the verb 'be'. All the other verbs are combinations of this verb with attributes, thus "attributive verbs" $(1816,95)$. This thesis stems from general grammar and goes back to Aristotle (Metaph. 4, 7, 6), who claims that there is no difference between ánthrōpos badizei 'the man walks' and ánthrōpos badizōn esti 'the man is walking'. This is why the copula was called verbum substantivum (e.g. by Franciscus Sanctius) or verbum abstractum in general grammar and subsequently by Bopp.

Faithful to this doctrine, whenever a conjugation ending contains the consonant $s$, Bopp is tempted to diagnose agglutination of some form of the Sanskrit root as- 'be' to the verb stem. Likewise, when a conjugation ending contains $b$ or some other labial consonant, this is traced back to Sanskrit $b h \bar{u}$-, also 'be'. This is the analysis Bopp $(1816,29 \mathrm{f})$ bestows, among many others, to the Sanskrit future II ending in $-s j \bar{a}$, which he reconstructs as the "future of the root $A s$, which no longer occurs in isolated form". On p. 33, he presents analogous arguments for the Sanskrit conditional. The same goes for the Greek aorist in -s-, the Sanskrit second past (o.c. 65f) and the Greek future in -s- (p. 66). Bhi - is found (p. 96) in the Latin imperfect suffix -ba-and the future

\footnotetext{
7 "New words may evolve in derived languages by new compositions of meaningful syllables, following the principle of the proto-language; and new grammatical forms evolve when the secondary specifications of a meaning, which in the proto-language were expressed by inflection of the stem syllable itself, are
}

indicated in an appended word, whose components are regarded as desinences of the stem syllable once the combination is no longer recognized. - In possum - pot-sum, we have an example where in present tense, a verbum abstractum is combined with an attributive root". 
suffix - bi-. However, Bopp does not explain how the same formative can fulfill so different functions, nor what the internal grammatical structure of the assumed periphrastic formation is. When he sees no way of deriving a desinence from the verb 'be', he often opts for "eine zufällige Einschaltung" (a fortuitous intercalation) (p. 119).

However, Bopp is open to auxiliaries of other lexical sources. One of his hypotheses that persist to our day is his analysis $(1816,151-157)$ of the Gothic past tense of the kind sokidedun 'they searched': it is composed of the root with the past of the auxiliary 'do'.

A variant of the agglutination of an auxiliary is the derivation of personal conjugation endings by the agglutination of pronouns. Bopp compares $(1816,147)$ Sanskrit $\underline{m a} m$ 'me' and tam 'him' with bhavami 'I am' and bhavati 'he is' and concludes:

"Es scheint mir keinem Zweifel mehr unterworfen zu seyn, dass die Buchstaben, die ich in diesem Versuche Kennzeichen der Personen zu nennen pflegte, wirkliche Pronomina seyen" 8 ".

Other examples of pronominal elements which Bopp analyzes as grammaticalized include the Ancient Greek definite article, derived from a demonstrative pronoun (1816, 70f). The complementizer 'that' in the Indo-European languages derives from a neuter demonstrative or relative pronoun in the accusative or some other dependent case. And here $(1816,79 \mathrm{f})$ there is one of the, alas, few occasions where Bopp does provide the syntactic conditions for his morphological analysis': the complementizer shows the case required by the governing verbum dicendi/sentiendi etc., so the finite complement clause itself does not need to show it. Again (p. 81-84), several subordinative conjunctions are analyzed as case forms of pronouns which determine or anticipate cataphorically the following verbal construction. Likewise (p. 127), the Gothic relative pronoun evolves from the demonstrative.

The nominative singular suffix $-s$ of certain Sanskrit declensions is traced back to the pronoun stem $s a$ - 'he' $(1833,157)$. Another analysis in the nominal sphere - and this one, too, survives to this day- concerns the definite adjective known from Old Church Slavonic and Lithuanian. Bopp $(1833,366 f)$ reconstructs it as the combination of a declined adjective with a declined pronoun. His observation on the modern descendant of this adjectival form in contemporary German is worth quoting:

"In dem Begreifen der definiten Adjectiv-Declination aber war die grammatische Wissenschaft, die sich in vielen anderen Punkten schon über das empirische Sprachgefühl erhoben hatte, noch hinter demselben zurückgeblieben, und wir fühlten in Formen wie guter, gutem, gute mehr als wir erkannten, nämlich ein Pronomen, welches noch geistig wirkt, wo es nicht mehr leiblich vorhanden ist ${ }^{10 "}$.

By this, Bopp means the following: Speakers of German would never combine a form like guter - successor to the reconstructed definite adjective form — with the definite article, feeling that

8 "It no longer seems to me subject to doubt that those letters which I used to call person marks in the present essay are real pronouns".

9 The bulk of his syntactic analyses is found in the sections on non-finite verb forms, e.g. the Ancient Greek infinitive (1816, 70-77). Their purpose is to demonstrate the origin of the infinitive in a cased noun.
10 "Concerning the understanding of the definite adjective declension, grammatical science, although meanwhile in many respects advanced beyond empirical linguistic intuition, had still fallen short of the latter; and in forms like guter, gutem, gute, we felt more than we recognized, viz. a pronoun which keeps acting mentally where it is no longer present physically". 
guter already contains a pronominal form - something that "grammatical science" had to wait for Bopp to discover. The constraint on the combination of this adjective form is the kind of phenomenon known as persistence (Hopper 1991) in today's grammaticalization theory.

Another grammatical domain where grammaticalization phenomena are recognized is occupied by particles, conjunctions and prepositions, which Bopp (1833, Vorrede zu Teil I: XVII) intends to derive from pronominal formations. This regards forms like English thus and therefore, which obviously incorporate demonstrative forms.

\section{Agglutination theory}

As we have seen, Bopp applied a set of ideas to the diachronic analysis of forms of Indo-European languages and to the reconstruction of proto-forms, but did not propose them in the form of a theory. A pupil of Schlegel's, Christian Lassen, dubbed Bopp's approach Agglutinationstheorie, in an article (1830) which was rather critical of Bopp's work and where the term Agglutinationstheorie was meant in the same contemptuous sense as the term impressionist was first meant when applied to Claude Monet and his group. Nevertheless, in the further course of the $19^{\text {th }}$ century, this was the term by which the theory became known and established. Here is how Bopp (1827 [1836], 1) characterizes his theory:

"Die Sprachen sind nämlich als organische Naturkörper anzusehen, die nach bestimmten Gesetzen sich bilden, ein inneres Lebensprinzip in sich tragend sich entwickeln und nach und nach absterben, indem sie, sich selber nicht mehr begreifend, die ursprünglich bedeutsamen, aber nach und nach zu einer mehr äußerlichen Masse gewordenen Glieder oder Formen ablegen oder verstümmeln oder mißbrauchen, d. h. zu Zwecken verwenden, wozu sie ihrem Ursprunge nach nicht geeignet waren ${ }^{11 ”}$.

There is much to be criticized in this partly very weird formulation. However, it is clear that Bopp envisages a gradual loss in autonomy of erstwhile meaningful linguistic units, which is still a valid concept in today's grammaticalization theory. Especially noteworthy is his observation that grammaticalized elements are used for functions which they were not meant to fulfill at their origin. This foreshadows modern theories of the expansion of grammaticalized elements, with accompanying loss of original motivation and passage into arbitrariness. From the above thesis, Bopp $(1833,111)$ derives a research program:

"Erkennen wir [hortative!] also in den Flexionen des Sanskritischen Sprachstamms keine inneren Umbiegungen der Wurzel, sondern für sich bedeutsame Elemente, deren Ursprung nachzuweisen die Aufgabe der wissenschaftlichen Grammatik ist ${ }^{12}$ ".

\footnotetext{
11 "For languages have to be regarded as organic natural bodies, which form according to certain laws, evolve bearing in themselves an inner life principle and gradually fade away. The way this happens is the following: No longer understanding themselves, languages dispose of members or forms which originally were meaningful, but little by little have become a rather superficial mass; they give them up, mutilate them or mis-
}

use them, i.e. they use them to purposes for which they were not apt by their origin".

12 "Let us then recognize in the inflections of the Sanscritic language phylum not inner modifications of the root, but elements which are meaningful in themselves and the demonstration of whose origin is the task of scientific grammar". 
As already mentioned, the recent success of the sciences loomed large over incipient Indo-European linguistics. On this background, the frequent dropping of the word Gesetz (law) in $1827^{13}$ and then in 1833 becomes understandable. In this spirit, Bopp $(1827,251=1836,3)$ assigns the following task to grammar:

"Eine Grammatik in höherem, wissenschaftlichem Sinne soll eine Geschichte und Naturbeschreibung der Sprache sein; sie soll .. . naturhistorisch die Gesetze verfolgen, nach welchen ihre Entwicklung ... vor sich gegangen ${ }^{14 ”}$.

Likewise, in the preface to part II of the Vergleichende Grammatik (p. IVf), he requires that the linguist recognize conditioning of linguistic variation by "general laws" and claims to have found one himself. It should be noted, in all fairness, that none of Bopp's explanatory hypotheses would receive the status of a general law by the standards of science. It remains the task of modern grammaticalization theory to set up its bases in the form of laws.

\section{THE FURTHER COURSE OF AGgLUTINATION THEORY}

The above sections prove that there is much grammaticalization in Bopp avant la lettre. As already mentioned, the same ideas were pursued simultaneously with Bopp by August W. Schlegel and Wilhelm von Humboldt. Humboldt's theory of linguistic evolution incorporates —even though in a much more general and explicit theoretical form - many of Bopp's ideas. In his academic lecture on the origins of grammatical forms, Humboldt $(1822,54 \mathrm{f})$ proposes that "grammatische Bezeichnung" (the signifying of grammatical categories, as opposed to objects) evolves through the following four stages:

I. "grammatische Bezeichnung durch Redensarten, Phrasen, Sätze”: grammatical categories are completely hidden in the lexemes and in the semantosyntactic configurations;

II. "grammatische Bezeichnung durch feste Wortstellungen und zwischen Sach- und Formbedeutung schwankende Wörter";

III. "grammatische Bezeichnung durch Analoga von Formen": here the "vacillating words" have been agglutinated as affixes to the main words. The resulting complexes are not "forms", unitary wholes, but only "aggregates", and therefore mere "analogs to forms";

IV. "grammatische Bezeichnung durch wahre Formen, durch Beugung und rein grammatische Wörter". 15

These stages are connected with each other "durch verloren gehende Bedeutung der Elemente und Abschleifung der Laute in langem Gebrauch." 16 These two correlative processes are known in modern grammaticalization theory as bleaching and erosion. The passage quoted sets the stage

13 It does not occur in Bopp 1816. The only passage that comes close to it is on p. 126, where Bopp attributes to the Gothic language "obedience with severe regularity" of some linguistic analogy.

14 "A grammar in a higher, scientific sense is to be a history and natural description of the language; it is ... to pursue in the way of natural history the laws by which its evolution ... has taken place”.
15 "I. grammatical signification by locutions, phrases, sentences; II. grammatical signification by fixed word order and words vacillating between material and formal meaning; III. grammatical signification by analogues of forms; IV. grammatical signification by true forms, by inflection and purely grammatical words".

16 "By the loss of meaning of the elements and abrasion of sounds in long use". 
for evolutive typology. It was taken up, in the nineteenth century, by Georg von der Gabelentz (1891), among others.

Agglutination theory got the status of a theory of grammatical change. It became the mainstream theory of the evolution of inflection in the $19^{\text {th }}$ century, defended by August Schleicher, who followed Humboldt in making agglutination theory the center of his evolutive typology. Several of the neogrammarians, among them Brugmann, were favorably inclined to the theory. Delbrück 1880 devotes an entire chapter to agglutination theory, approving of it with some reservations.

In conclusion, Bopp's contribution to grammaticalization studies may be appreciated as follows: He found the relevant ideas in his intellectual environment. He neither invented grammaticalization theory nor did he formulate it in a coherent and systematic way. What he did was apply it in innumerable historical and reconstructed cases. A sizable subset of these are perfectly sound hypotheses of the proper diachronic morphological analysis of word forms, which remain uncontested to this day and have even become common heritage in Indo-European linguistics. It was the impact of the sheer quantity of Bopp's plausible and fruitful analyses that promoted grammaticalization theory, in the form of agglutination theory, in $19^{\text {th }}$ century linguistics and helped to grant it a place in modern linguistics.

\section{REFERENCES}

Bernabé Pajares, A., 1983, «El descubrimiento del sánscrito: tradición y novedad en la lingüística europea», Revista Española de Lingüistica 13, 81-92.

Bopp, F., 1816, Über das Conjugationssystem der Sanskritsprache in Vergleichung mit jenem der griechischen, lateinischen, persischen und germanischen Sprache. Nebst Episoden aus dem Ramajana und Mahabharata in genauen metrischen Übersetzungen aus dem Originaltexte und einigen Abschnitten aus den Vedas. Herausgegeben und mit Vorerinnerungen begleitet von Dr. K. J. Windischmann, Frankfurt/M: Andreäsche Buchhandlung.

—, 1827, «Über J. Grimms’s deutsche Grammatik», Jahrbücher für wissenschaftliche Kritik, Febr. 1827. Reprint in Bopp 1836, 1-134.

—, 1833-52, Vergleichende Grammatik des Sanskrit, Zend, Griechischen, Lateinischen, Litauischen, Altslawischen, Gothischen und Deutschen. 6 Abteilungen, I: 1833; II: 1835; III: 1837; IV: 1842; V: 1849; VI: 1852. Berlin: F. Dümmler.

—, 1836, Vocalismus oder sprachvergleichende Kritiken über J. Grimms deutsche Grammatik und Graffs althochdeutschen Sprachschatz, mit Begründung einer neuen Theorie des Ablauts. Berlin: Nicolai.

Condillac, É. B. de, 1746, Essai sur l'origine des connoissances humaines. Ouvrage où l'on réduit à un seul principe tout ce qui concerne l'entendement humain, 2 vols. Amsterdam: P. Mortier.

DelbrücK, B., 1880, Einleitung in das Sprachstudium. Ein Beitrag zur Geschichte und Methodik der vergleichenden Sprachforschung. Leipzig: Breitkopf \& Härtel.

Gabelentz, G. von der 1891, Die Sprachwissenschaft. Ihre Aufgaben, Methoden und bisherigen Ergebnisse, Leipzig: Weigel Nachf.

Grimm, J., 1819, Deutsche Grammatik, Theil 1. Göttingen: Dieterich.

Hopper, P. J., 1991, «On some principles of grammaticization», E. Closs Traugott \& B. Heine (eds.), Approaches to grammaticalization, 2 vols. Amsterdam \& Philadelphia: J. Benjamins (Typological Studies in Language, 19), 17-35.

HumboldT, W. von, 1822, «Über das Entstehen der grammatischen Formen und ihren Einfluß auf die Ideenentwicklung», Abhandlungen der historisch-philologischen Klasse der Königlichen Akademie der Wissenschaften zu Berlin. 
Humboldt, W. von, 1827, Lettre à M. Abel-Rémusat sur la nature des formes grammaticales en général et sur le génie de la langue chinoise en particulier, Paris: Dondey-Dupré.

—, 1836, Über die Verschiedenheit des menschlichen Sprachbaues und ibren Einfluß auf die geistige Entwicklung des Menschengeschlechtes (=Über die Kawi-Sprache auf der Insel Java. Einleitung), Berlin: KöniglichPreussische Akademie der Wissenschaften; in Kommission: Bonn etc.: F. Dümmler.

Lassen, Ch., 1830, «Über Herrn Professor Bopps grammatisches System der Sanskrit-Sprache», Indische Bibliothek 3, 1-113.

Lehmann, Ch., 2015, Thoughts on grammaticalization. 3rd edition 2015, Berlin: Language Science Press (Classics in Linguistics, 1).

Meillet, A., 1912, «L'évolution des formes grammaticales», Scientia 12 (26=6), 384-400.

Narrog, H., \& B. Heine (eds.), 2011, The Oxford handbook of grammaticalization, Oxford: Oxford University Press (Oxford Handbooks in Linguistics).

Paul, H., 1880, Prinzipien der Sprachgeschichte, Tübingen: M. Niemeyer.

Saussure, F. de, 1916, Cours de linguistique générale, publié par Charles Bally et Albert Séchehaye avec la collaboration de Albert Riedlinger, Paris: Payot.

Schlegel, A. W. von, 1818, Observations sur la langue et la littérature provençales, Paris: Librairie grecquelatine-allemande.

Schlegel, F., 1808, Ueber die Sprache und Weisheit der Indier. Ein Beitrag zur Begründung der Alterthumskunde. Nebst metrischen Übersetzngen indischer Gedichte. Heidelberg: Mohr \& Zimmer. 